\title{
The Characterization of Thermoelectric Generator in Utilizing the Heat Waste of the Biomass Egg Drying Machine
}

\author{
Sudarmanto Jayanegara ${ }^{\mathrm{a},{ }^{*}}$, Zuryati Djafar ${ }^{\mathrm{b}}$, Zulkifli Djafarc, Nasaruddin Azis ${ }^{\mathrm{d}}$, Wahyu Haryadi Piarah ${ }^{\mathrm{e}}$

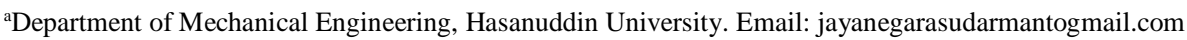 \\ bepartment of Mechanical Engineering, Hasanuddin University. Email: zuryatidjafar@unhas.ac.id \\ 'Department of Mechanical Engineering, Hasanuddin University. Email: zulkiflidjafar@unhas.ac.id \\ ${ }^{\mathrm{d}}$ Department of Mechanical Engineering, Hasanuddin University. Email: nasruddinazis@ unhas.ac.id \\ eDepartment of Mechanical Engineering, Hasanuddin University. Email: wahyupiarah@unhas.ac.id
}

\begin{abstract}
This research was conducted to determine the character of the TEG module as a source of electrical energy in utilizing heat in the chimney wall of an egg rack drying machine that uses rice husk as engine furnace fuel. The test is carried out by utilizing heat on 2 pieces of chimney (upper chimney and lower chimney) separated by a Heat Exchanger (HE) with a furnace blower speed of $2600 \mathrm{rpm}$ and environmental blower speed of $2800 \mathrm{rpm}$ with the amount of thermoelectric used as many as 44 units. The results show that the TEG module in the upper chimney obtained temperature difference $(\Delta \mathrm{T})$, voltage difference $(\Delta \mathrm{V})$ and power $(\mathrm{P})$ respectively $\Delta \mathrm{T}$ $38.75{ }^{\circ} \mathrm{C} ; \Delta \mathrm{V} 3.68$ Volts; P 0.796 Watt and for the lower chimney respectively $\Delta \mathrm{T} 73.25^{\circ} \mathrm{C} ; \Delta \mathrm{V} 12.26$ Volts; P $2.446 \mathrm{Watt}$.
\end{abstract}

Keywords: Characterization; egg rack dryer; TEG; temperature difference; voltage difference

\section{Introduction}

The electricity for humans in modern era is an irreplaceable need. Every activity undertaken is inseparable from the roles of electrical energy in order to facilitate all work. In Indonesia, electricity production tends to use fossil energy, especially coal, oil, and natural gas as its main raw material. But on the other hand, fossil energy is non-renewable energy whose nature will run out. Especially for petroleum fuels, it is estimated that it will run out no later than the end of the 21 st century and coal is predicted to run out approximately 200 to 300 years to come [1].

The total electricity generated by renewable energy in 2011 was 21.8 TWh or around $12 \%$ of the total electricity supplied at 183.2 TWh. Coal-fired, natural gas, and oilfired power plants are PLN's foundation in producing electricity. All three resources are accounted for nearly $80 \%$ of the total electricity generated [2].

Several renewable energy sources can be used to generate electricity, including: First, power plants with macro capacity that usually utilize water, steam, gas, nuclear, and others. Second, power plants with micro

${ }^{\star}$ Corresponding author. Tel.: +62 852-8404-1817

Jalan Poros Malino km. 6 Bontomarannu

Gowa, Sulsel, Indonesia capacity, one of which utilizes thermal energy [3]. The heat energy, among others, comes from sunlight and objects that release heat, such as irons, motor vehicle exhausts, heating stoves, drying machines, and so on. Although the power plant is only micro-capacity, the maximum use in the long run can help conserve the use of electricity generated by macro-capacity power plants. Macro-capacity power plants should only be used to meet the needs of high-power electricity. Meanwhile, for the fulfillment of small-scale electricity, such as lighting lamps, can utilize micro-capacity power plants.

Micro-capacity power plants can generally utilize renewable energy sources where one source is heat energy. In this paper, the source of heat energy is obtained from the surface of the egg rack drying machine chimney. The egg rack drying machine, aside from being used as a dryer, can also be used as a source of electrical energy by converting wasted heat energy into electrical energy.

\section{Literature Review}

Thermoelectric technology is one alternative energy source in overcoming the energy crisis from year to year [4]. This technology is a solid-state technology that is not moving and environmentally friendly [5], [6]. 


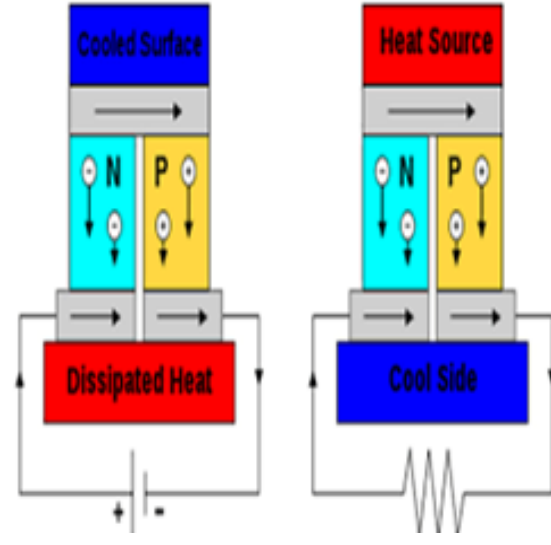

Figure 1. Mechanism of the Seebeck effect [14]

Thermoelectric Generator (TEG) is a type of power plant that is based on the principle of the Seebeck effect that was first discovered by scientist Thomas Johan in 1821 [7]-[9].

The Seebeck effect is that if two metal materials (usually semi-conductors) which are interconnected are in an environment with a temperature difference then the material will produce a difference in voltage or electromotive force [10]. In Fig. 1, type $\mathrm{n}$ semiconductor will produce negative potential on the cold side and positive potential on the remaining heat so that electrons will move from positive to negative potentials, while the p-type semiconductor is vice versa [11]-[13]. The resulting voltage is proportional to the temperature difference between the two materials. The greater the temperature difference, the greater the voltage produced.

The egg rack is a container that functions to store and arrange the eggs produced by the chickens so that they do not easily crack and facilitate the sales transaction process [14]. The process of drying the egg rack (after printing) can use two methods namely with the help of sunlight and using a drying machine [15]. The egg rack drying machine with a rice husk stove serves as a substitute for the drying process in the rainy season [16].

\section{Research Methodology}

In this paper, the research is focused on the utilization of waste heat on the surface of the chimney. Where the chimney is divided into 2 parts. The lower side is in direct contact with the furnace and the upper-side is separated by the Heat Exchanger (see Fig. 2). The equipment used was at one of PT. Rak Nusantara, one of the producers of egg racks in Batu Lappa, Wattang Pulu Subdistrict, Sidenreng Rappang District (3055 '22 "LS and 119054 " 39.3 "BT).

Figure 2 is the design of testing equipment where the sampling points are in the upper chimney and the lower chimney. Aluminum plates with a thickness of $3 \mathrm{~mm}$ are placed in the upper chimney and the lower chimney as a TEG module holder which functions to utilize wasted heat to produce electricity. In this test, 8 TEG modules for the upper chimney and 36 TEG modules for the lower chimney that are installed spread out with an electric series circuit (Figs. 3 and 4). Heatsink cooler and fan are mounted on top of the TEG module which serves to dissipate heat on the cold side so that the temperature difference can be more maximal.

The output voltage of the TEG module is measured by using a multimeter after a while getting heat flow from the aluminum plate. Measuring the temperature of the hot side $(\mathrm{Th})$, cold side (Tc) and voltage $(\Delta \mathrm{V})$ of the TEG module is done with an interval of 5 minutes for 120 minutes (the burning process) and then carried out measurements with an interval of 5 minutes for 60 minutes (Process without burning). The data obtained is then recorded in the observation table.

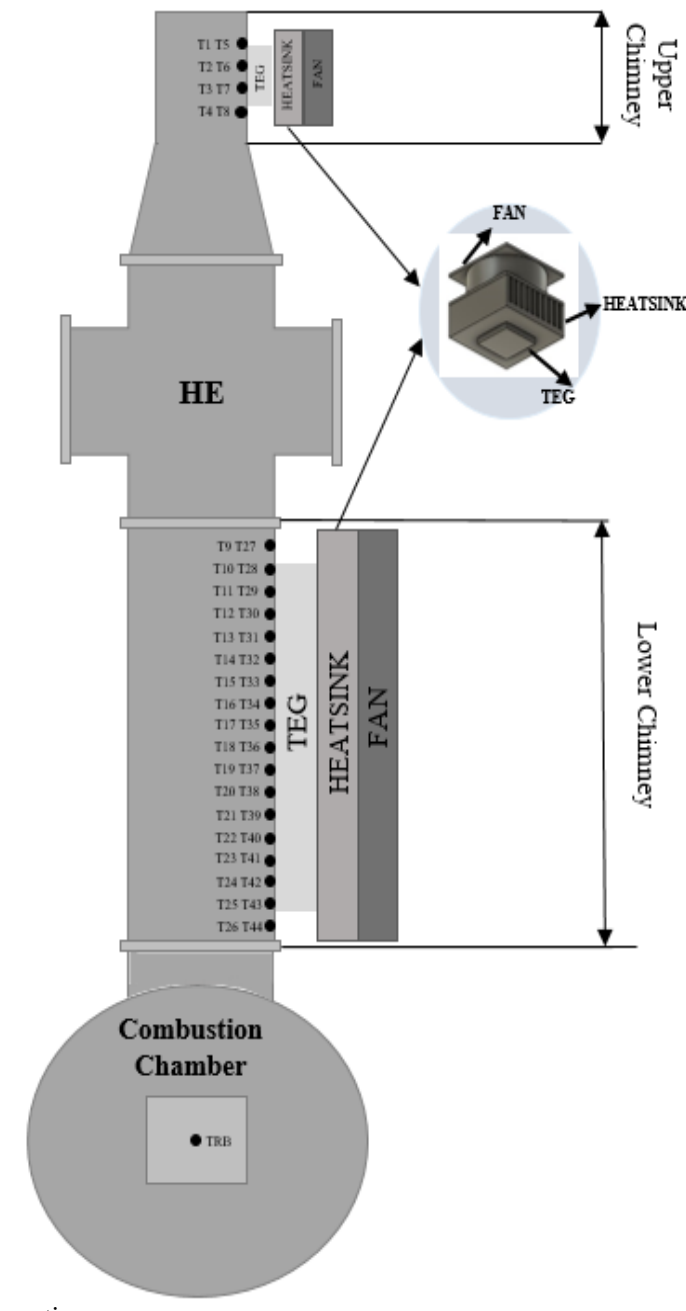

Information:

- Combustion Temperature (TRB) measurement point

- Lower Chimney Temperature measurement points $\left(\mathrm{T}_{9}\right.$ to $\left.\mathrm{T}_{44}\right)$

- Upper Chimney Temperature measurement points $\left(\mathrm{T}_{1}\right.$ to $\left.\mathrm{T}_{8}\right)$

Figure 2. Test equipment design

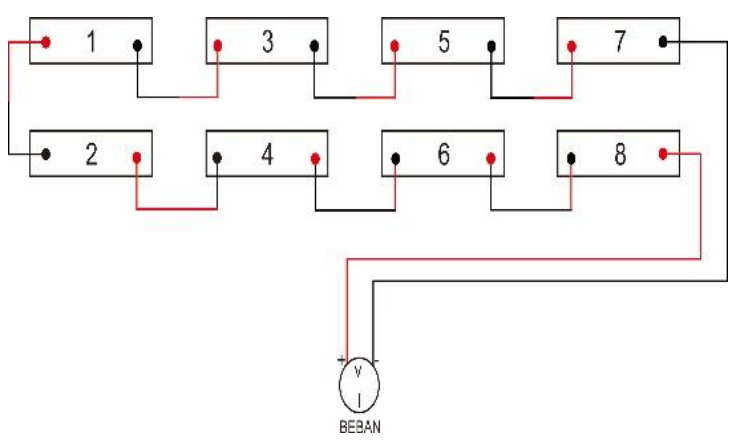

Figure 3. The upper chimney electric series (8 TEG) 


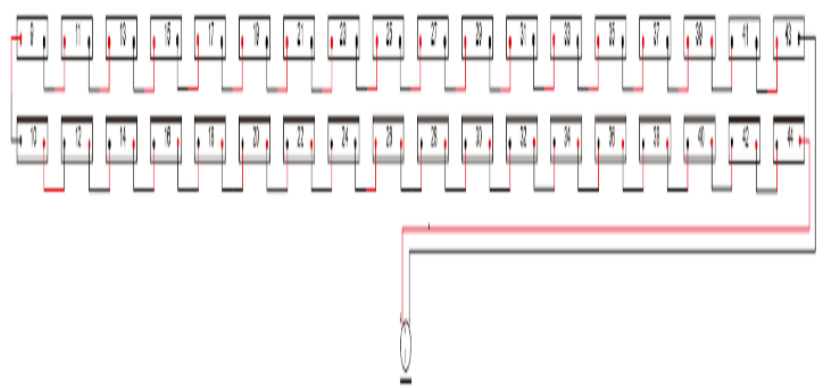

Figure 4. The lower chimney electric series (36 TEG)

Voltage generated from thermoelectric modules due to temperature differences will cause an electric current. The electric current equation can be stated in the following equation [17], [18]

$$
I=\frac{\alpha \Delta T}{R_{i}+R_{L}}=\frac{\alpha\left(T_{h}-T_{c}\right)}{R_{i}+R_{L}}
$$

where

$I=$ Electric currect flowing in circuit (A)

$R_{i}=$ Thermoelectric module internal resistance $(\Omega)$

$R_{L}=$ External resistance $(\Omega)$

$\Delta T=T_{h}-T_{c}$

$$
\alpha=\frac{\Delta V}{(\Delta T)}
$$

while the rate of heat transfer $(\mathrm{Qh})$ from the heat source on the hot side surface $\left(T_{h}\right)$ to the cold side surface $\left(T_{c}\right)$ is as follows [15]

$$
Q h=\left(\alpha I T_{h}\right)+k\left(T_{h}-T_{c}\right)
$$

where $k$ is the module thermal conductivity $\left(\mathrm{W} / \mathrm{m}{ }^{\circ} \mathrm{C}\right)$. The output power $(\mathrm{P})$ produced against the external load [17] and the efficiency $(\eta)$ of the Thermoelectric Generator is as follows [19].

$$
\begin{gathered}
P=I^{2} R_{L} \\
\eta=\frac{P}{Q_{h}}
\end{gathered}
$$

\section{Result and Discussion}

\subsection{Historical graphs of hot and cold temperatures}

Figure 5 shows the history of the average temperature of the hot side and the average temperature of the cold side of the upper chimney and the lower chimney which has increased since the initial minutes of burning until the 120th minute (end of the burning process) with values of $113.5{ }^{\circ} \mathrm{C}$ respectively. (TUCh on average), $74.75{ }^{\circ} \mathrm{C}$ (TUCc on average), and $210.92{ }^{\circ} \mathrm{C}$ (TLCh on average), $137.67{ }^{\circ} \mathrm{C}$ (TLCc on average). Furthermore, it has decreased to near the ambient temperature in the 180th minute. This is due to the burning process occurs continuously over time until the fuel (rice husk) runs out. Furthermore, it can be seen that the temperature of the lower chimney has a higher value compared to the upper chimney because the position of the lower chimney is just above the burning chamber (furnace).

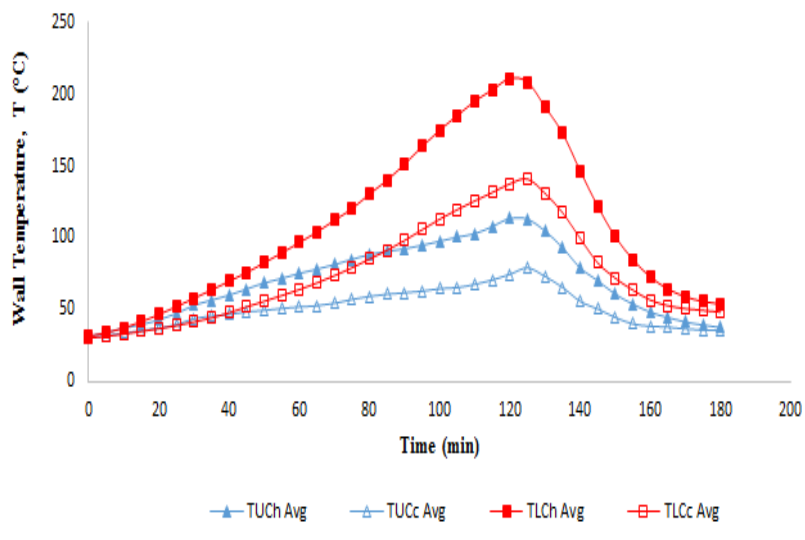

Figure 5. $\mathrm{T}_{\mathrm{H}}$ avg and $\mathrm{T}_{\mathrm{C}}$ avg in the upper and lower chimney of the TEG module

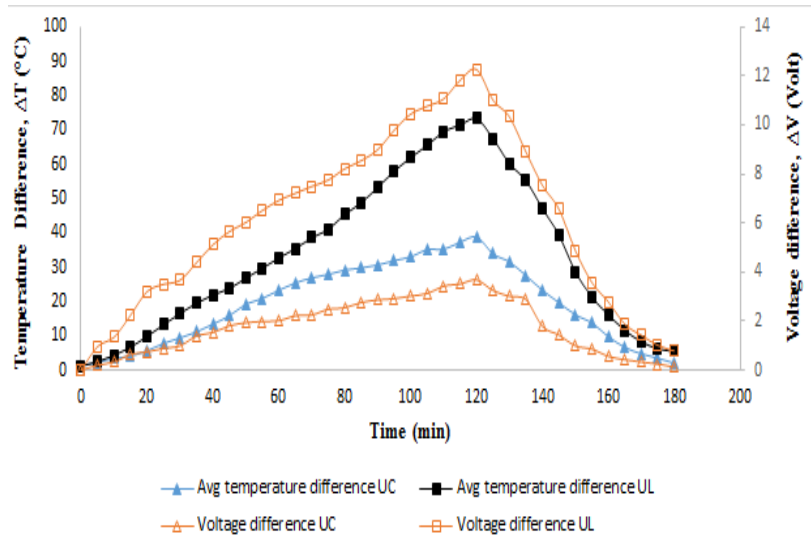

Figure 6. Average $\Delta \mathrm{T}$ and $\Delta \mathrm{V}$ in the upper chimney and lower chimney of the TEG module

\subsection{Graph of the average temperature difference and voltage difference}

In Fig. 6, it can be seen that the difference in average temperature in the upper and lower chimneys reaches a peak in the 120th minute with values of $38.75^{\circ} \mathrm{C}$ for UC and $73.25{ }^{\circ} \mathrm{C}$ for LC. While the voltage with each is 3.68 Volts for UC and 12.26 Volts for LC. The difference in voltage obtained along with the temperature difference at each chimney an increase.

\subsection{Graph of heat absorbed}

Figure 7 shows the heat absorbed in the upper chimney and the lower chimney for the TEG module which has increased since the initial minutes of combustion until the 120th minute with values respectively 38.69 Watt for UC and 293.66 Watt for LC. Furthermore, it decreased in the 180th minute. This was also affected by the thermal conductivity of an aluminum plate and heat transfer.

\subsection{Electric power graph}

In Fig. 8 it can be seen if the power generated in the upper and lower chimneys reaches their peak in the 120th minute with values of 0.179 Watt for UC and 2.445 Watt for LC respectively. Furthermore, it decreases in the 180th minute until the total power can no longer be produced. 


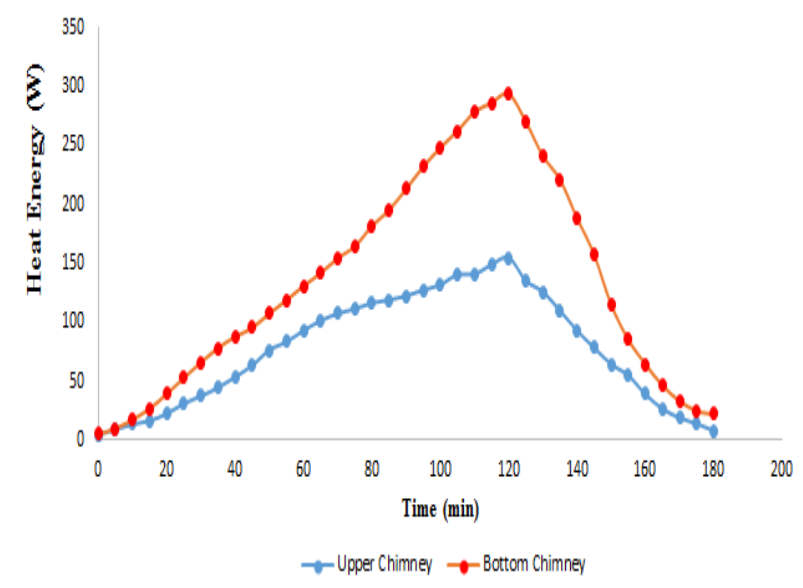

Figure 7. QH in the upper chimney and the lower chimney of the TEG module

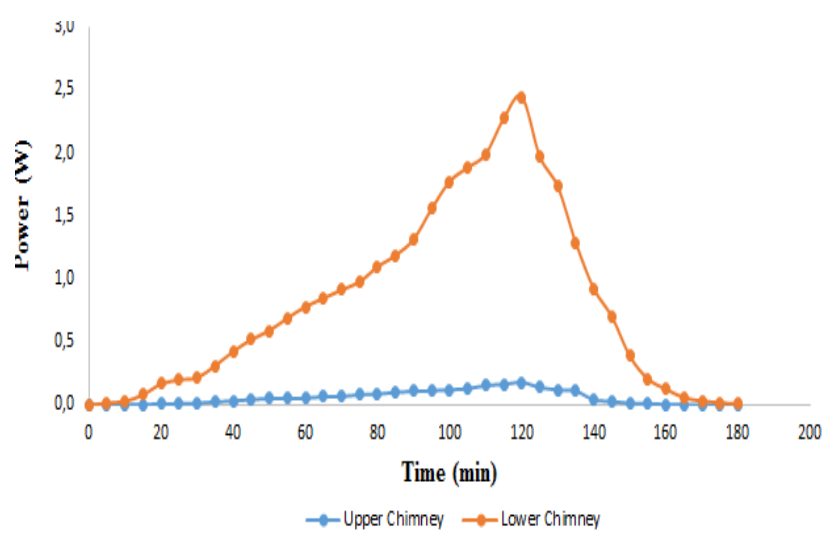

Figure 8. Electric power $(\mathrm{P})$ in the upper and lower chimney of the TEG module

\subsection{TEG module Efficiency Graph}

Figure 9 shows that the efficiency of the upper chimney and the lower chimney has peak values of $0.12 \%$ and $0.83 \%$, respectively. The efficiency value is still relatively small. This is because the TEG used is of low quality (Non-Branded).

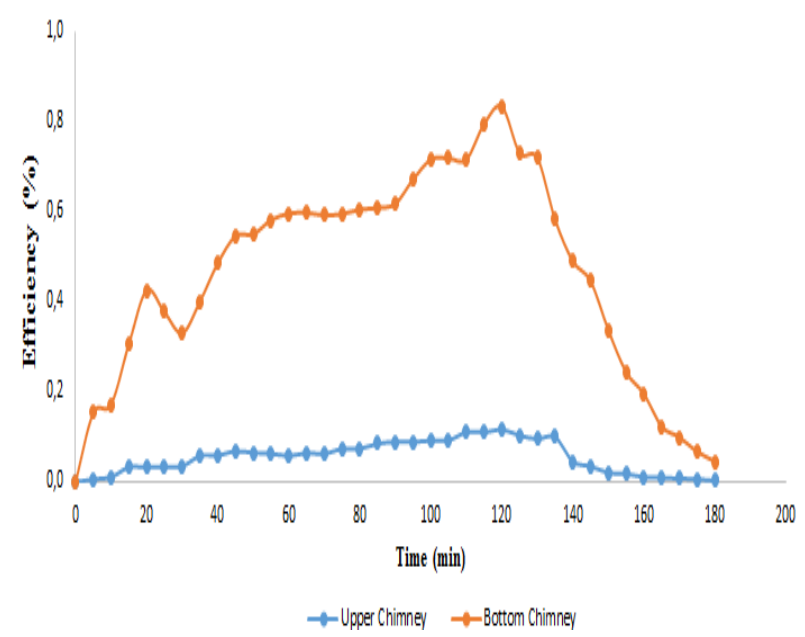

Figure 9. Efficiency $(\eta)$ in the upper chimney and lower chimney of the TEG module

\section{Conclusion}

The test results show that with 8 modules thermoelectric element generator (TEG) in the upper chimney and 36 TEG modules in the lower chimney which are arranged in series can produce an output voltage with a maximum temperature difference of each $\Delta \mathrm{V} 3.68$ Volts; $\Delta \mathrm{T} 38.75^{\circ} \mathrm{C}$ for the upper chimney, and $\Delta \mathrm{V} 12.26$ Volts; $\Delta \mathrm{T} 73.25^{\circ} \mathrm{C}$ for the lower chimney. The potential power that can be produced is $0.179 \mathrm{~W}$ (UC) and $2.445 \mathrm{~W}$ (LC). This research is very good and effective as a future prospect to help in saving and using electricity in the future.

\section{Reference}

[1] A. Pudjanarsa and D. Nursuhud, Energy Conversion Machine, 2nd ed. Yogyakarta: ANDI, 2008.

[2] Center of Data and Information of Energy and Mineral Resources, Study of Indonesian Energy Outlook. Kementerian Energi dan Sumber Daya Alam, 2012.

[3] Center of Data and Information of Energy and Mineral Resources, Study of Supplying and the Utilization of Migas, Batubara, EBT dan Listrik. 2017.

[4] S. Nugrah, A. Aziz, and R. I. Mainil, "The Testing of Thermoelektric Generator (TEG) with Heat Source Electric Heater 60 Volt Using Cold Water at Environment Temperature," J. Online Mhs. Fak. Tek. Univ. Riau, vol. 4, no. 2, 2017.

[5] Y. Prasetyo et al., "Characteristic of Thermoelectric TEC Varies Type With Variation Load Resistor," J. Energi dan Teknol. Manufaktur, vol. 2, pp. 36-41, 2019.

[6] M. A. Pradana and M. Widyartono, "Prototipe Pembangkit Listrik Termoelektrik Generator Menggunakan Penghantar Panas Aluminium, Kuningan dan Seng," J. Tek. Elektro, vol. 9, pp. 251258,2020

[7] K. Khoiriyah, Mustaqimah, A. S. F. Al Maliin, M. T. Maaulana, and N. I. Kamal, "Design and Characteristic of Thermoelectric Generator by using Solar Energy," in Prosiding Seminar Nasional Fisika (SINAFI), 2018.

[8] M. Ilham, Rizki, M. A. Nurdin, S. E. M. Putra, Hanani, and R. Hidayat, Module 3 Thermoelectric. ITB, 2013.

[9] R. Abrar, M. R. Fauzi, and B. Istana, "Optimization of Waste Heat Utilization in Biomass Gasification Furnaces as Electricity Generators," in Simposium Nasional Teknologi Terapan (SNTI) 2, 2014.

[10] S. Klara and Sutrisno, "Utilization of Diesel Engine Exhaust Gas Heat as Electrical Energy," Res. J. Mar. Technol., vol. 14, no. 1, 2016.

[11] H. Simatupang, Characteristics Thermoelectric for Solar Power Plants with Water Cooling. Yogyakarta: Mechanical Engineering Study Program, Science and Technology Faculty, 2019.

[12] Sugiyanti and S. Siswantoro, "Utilization of Heat in LPG Gas Stoves for Electric Energy Charge Using a Thermoelectric Generator," J. Technol., vol. 7, no. 2, pp. 100-105, 2014.

[13] G. Min and D. M. Roe, Handbook of Thermoelectric, Peltier Devices as Generator. Florida: CRC Press LLC, 1994.

[14] H. A. Liemana, D. Lestariningsih, and L. Agustinne, "Automatic Carton Egg Tray Drying System above the Cart," Widya Tek., vol. 6, no. 2, pp. 152-162, 2007.

[15] P. Kurniasih, "Business Feasibility of Making Egg Packaging Products from Waste Paper in West Sumatra," For. Soc. Econ. Res., vol. 10, no. 3, pp. 152-172, 2013.

[16] B. Syarifuddin, Analysis of the Effectiveness of a Heat Exchanger on an Egg Rack Dryer Machine with a Rice Husk Fired Furnace. Makassar: Fakultas Teknik Universitas Hasanuddin, 2018.

[17] H. J. Goldsmid, "Introduction to Thermoelectricity," Springer Ser. Mater. Sci., vol. 121, 2010.

[18] N. Putra, W. N. Septiadi, H. Rahman, and R. Irwansyah, "Thermal Performance of Screen Mesh Wick Heat Pipes with Nanofluids," Therm. Fluid Sci. 40, pp. 10-17, 2012.

[19] R. Saleha, N. Putra, S. P. Prakoso, and W. N. Septiadi, "Experimental investigation of thermal conductivity and heat pipe thermal performance of $\mathrm{ZnO}$ nanofluids," Int. J. Therm. Sci., vol. 63, pp. 125-132, 2013. 